\title{
HABITAT PREFERENCES OF OXYCOCCUS PALUSTRIS PERS. ON PEATLANDS IN EAST POLAND IN THE PERSPECTIVE OF SHAPING THE CONDITIONS OF ECOLOGICAL CULTIVATION OF THE SPECIES
}

\author{
SERAFIN, A. ${ }^{1}$ - POGORZELEC, M. $^{2}$ - BRONOWICKA-MIELNICZUK, U. ${ }^{3 *}$ \\ ${ }^{I}$ Department of Environmental Engineering and Geodesy, University of Life Sciences in Lublin \\ Leszczyńskiego 58, 20-068 Lublin, Poland \\ ${ }^{2}$ Department of Hydrobiology and Protection of Ecosystems, University of Life Sciences in \\ Lublin, Dobrzańskiego 37, 20-262 Lublin, Poland \\ ${ }^{3}$ Department of Applied Mathematics and Computer Science, University of Life Sciences in \\ Lublin, Gtęboka 28, 20-612 Lublin, Poland \\ *Corresponding author \\ e-mail: urszula.bronowicka@up.lublin.pl; phone: +48-81-532-9626
}

(Received $4^{\text {th }}$ Apr 2018; accepted $30^{\text {th }}$ May 2018)

\begin{abstract}
The objective of the paper was the determination of values of selected habitat conditions optimal for Oxycoccus palustris Pers. on peatlands in the central part of East Poland in the aspect of provision of proper conditions in ecological cultivations of the plant. The obtained results showed a broad range of ecological tolerance towards the analysed physical-chemical properties of the habitat, however not the exceeding values typical of the occupied habitat, as evidenced by the relatively common occurrence of the species. Statistical analyses of the study results showed that important factors causing variability in the abundance and therefore condition of the population of the species at particular study sites include: $\mathrm{P}_{\text {total }}, \mathrm{P}_{-} \mathrm{PO}_{4}$, and DOC (dissolved organic carbon). Ranges of values of the factors optimal for the functioning of the O. palustris population on the studied habitats were specified $\left(\mathrm{P}_{\text {total }}=0.17\right.$ $0.36 ; \mathrm{P}-\mathrm{PO} 4=0.1$ and $\mathrm{DOC}=33.81-55.90\left[\mathrm{mg} \mathrm{dm}^{-3}\right]$ ).
\end{abstract}

Keywords: small cranberry, herbs, physical-chemical properties, phytotherapy

\section{Introduction}

The medicinal effect of active natural substances of plants on the patient's organism and the complex provision of easily available biofactors (e.g. vitamins, enzymes, or micro- and macroelements) in phytotherapy constitutes a desirable alternative for synthetic pharmacology, related to unhealthy side effects and dangerous polypharmacy (Nowiński, 1983; Brinkmann et al., 2007; Buettner et al., 2009; Drozd, 2012; Oliveira et al., 2012; Skotnicka, 2013; Senderski, 2015).

One of the most valued herbal plants obtained from nature and to a lower degree from cultivation is small cranberry (Oxycoccus palustris Pers.). In morphological terms, it is a shrub from the ericaceous family (Ericaceae) with delicate, creeping shoots reaching a height of $100 \mathrm{~cm}$. It has small, leathery, evergreen leaves with elliptical shape. The flowers usually grow by 3-4 on long stalks. They are pink with petals folded downwards. The fruit is a spherical, multi-seed, juicy, red berry. It blooms in the moderate climate from June to August. The fruit matures in September, remaining on the shoot until early spring. It occurs in the countries of North and Central Europe, North Asia, and North America, and in Poland on wetlands related to ombrogenic peatlands (Jaquemart, 1997; Arnal et al., 2008; Senderski, 2015). 
In terms of life strategy, Oxycoccus palustris is a perennial chamephyte preferring sites on organogenic soils characteristic of raised or transitional bogs, oligotrophic, with a lower reaction and parameters of circumboreal climate, moisturised, with moderate light conditions (Jaquemart, 1997; Zarzycki and Korzeniak, 2002; Senderski, 2015).

The herbal resource is the cranberry fruit containing many bioactive substances, i.e. acids: benzoic, citric, malic, gallic, quinic, ascorbic; anthocyanins, carotenoids, flavonoids, pectins, tannins, carbohydrates, mineral substances, including iodine salts, and leaves containing glycoside arbutin (Česonienè et al., 2006; Adamczak et al., 2009; Lyutikova and Turov, 2011; Senderski, 2015). Extracts from cranberry fruit are applied as a refreshing and immunosuppressive agent, and as auxiliary medicine in urinary infections. The leaves are used as astringent and disinfectant, and to stop bleeding (Jepson and Craig, 2008; Ruzik-Kuklińska, 2010; Senderski, 2015).

Herbal plants at natural sites of occurrence, in the conditions of low human pressure, show a natural content and proportion of biologically active components translating into high quality herbal resources (Lyutikova and Turov, 2011). Medicinal products manufactured in accordance with the rules of Good Manufacturing Practice (GMP) from such plants meet the optimum assumptions of the natural herbal medicine pursuant to the guidelines of WHO (Borkowski, 1994; Drozd, 2012). Due to the above, an alternative worth considering can be ecological cultivations conducted under conditions adjusted to the natural preferences of plants.

The objective of this paper was the determination of optimal values of selected habitat conditions important for the proper functioning of Oxycoccus palustris in the peatlands of the central part of East Poland in the aspect of provision of proper conditions in ecological cultivations of the plant. The lack of available source texts regarding the qualitative analysis of the habitat factors of cranberry at natural sites of its occurrence is an additional argument for undertaking this research.

\section{Material and methods}

\section{Fieldwork}

The research was conducted in the area of peatlands of the central part of East Poland included in the Łęczna-Włodawa Lakeland (Polesie Podleskie). After preliminary reconnaissance, six representative sites were selected with plant species composition characteristic of the analysed region, where the presence of the population of $O$. palustris was observed within or near the Poleski National Park: lake-peatland complexes: Lake Bikcze (B), Lake Karaśne (K), Lake Długie (D), Lake Moszne (M), forest peatland Blizionki (BZ) and Dekowina (DK) - Figure 1.

Research areas (plots) of $100 \mathrm{~m}^{2}(10 \mathrm{~m} \times 10 \mathrm{~m})$ were designated at study sites. Their phytocoenoses were characterised by variable contribution of $O$. palustris. In the vegetation season 2011, to confirm the correctness of the selection of study sites, the species composition of phytocoenoses of the plots was determined with consideration of percent contribution of particular species of vascular plants.

Piezometers were installed in the central part of the sites (perforated PVC pipe with a length of $1 \mathrm{~m}$ and diameter of $10 \mathrm{~cm}$, dug into the ground) for sampling peatland water. Each year (in the years 2011-2013) in the vegetative season (from March to April), water was sampled from the piezometers seven times, and transported to the laboratory. Water reaction and electrolytic conductivity were also measured in situ by means of portable multiparameter meters. 


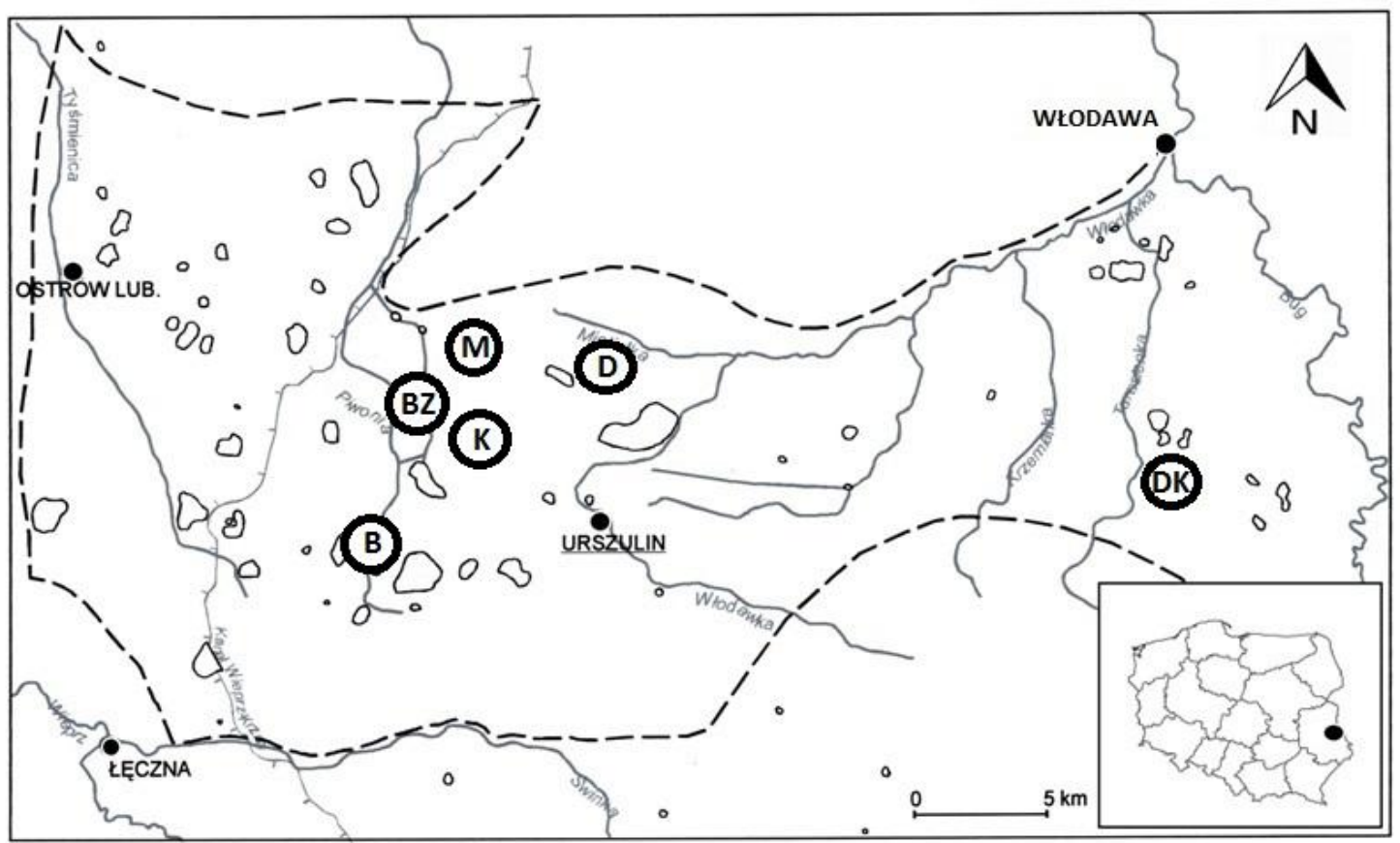

Figure 1. Location of the study sites in the Polesie Podlaskie Region in Poland (Serafin et al., 2017). (B-Bikcze, M- Moszne, K- Karaśne, D-Dtugie, BZ-Blizionki, DK-Dekowina)

\section{Laboratory analysis}

Laboratory analyses of the sampled piezometric waters were performed at the Central Agroecological Laboratory of the University of Life Sciences in Lublin (CLA) by means of certified methods. They covered 14 physical-chemical properties of peatland waters: reaction $(\mathrm{pH})$, electrolytic conductivity $(\mathrm{CON})$, dissolved organic carbon content (DOC), content of nitrogen fractions: total nitrogen $\left(\mathrm{N}_{\text {total }}\right)$, ammonia nitrogen $\left(\mathrm{N}-\mathrm{NH}_{4}\right)$, nitrates $\left(\mathrm{N}-\mathrm{NO}_{3}\right)$, nitrites $\left(\mathrm{N}-\mathrm{NO}_{2}\right)$, and content of phosphorus fractions: total phosphorus $\left(\mathrm{P}_{\text {total }}\right)$, phosphates $\left(\mathrm{P}-\mathrm{PO}_{4}\right)$, and concentration of sulphates $\left(\mathrm{S}_{-} \mathrm{SO}_{4}\right)$ and basic cations: potassium $(\mathrm{K})$, sodium $(\mathrm{Na})$, calcium $(\mathrm{Ca})$, and magnesium $(\mathrm{Mg})$.

\section{Data analysis}

The coefficient of species similarity of the phytocoenoses of plots was calculated by means of the Jaccard's method. It provided the basis for the classification analysis as the distance measure with the application of the classification algorithm of minimum variance (Ward clustering) for the species composition, and algorithm of complete linkage for habitats.

For the purpose of comparison of distributions of the values of the analysed properties in particular habitats, due to the lack of normality of their distribution and non-uniformity of variance within data sets, a non-parametric Kruskal-Wallis test was applied.

The ranges of values of selected environmental factors with statistical testing are presented graphically in the form of box-plots presenting particular properties of empirical distributions for two groups of study sites: B+BZ (sites with a low \% 
contribution of occurrence of $O$. palustris) and $\mathrm{M}+\mathrm{K}+\mathrm{D}+\mathrm{DK}$ (sites with a high $\%$ contribution of occurrence of $O$. palustris).

All the obtained values were analysed by means of direct ordinance methods. Based on the obtained value of gradient length (1.56), redundancy analysis (RDA) was applied. Selection of environmental variables was performed, adopting the absolute value of the correlation coefficient $>0.6$ as the rejection criterion (Zuur et al., 2007).

All statistical analyses were performed using packages: vegan (version 2.4-2), nortest, MASS and ggdendro in R environmental (R Core Team, 2015; Oksanen et al., 2016).

\section{Results and discussion}

The specificity of habitat conditions of the peatlands of Polesie Podlaskie in the central part of East Poland, involving specific microclimate, rich water relations, and relatively low human pressure, determines the possibilities of occurrence of many species of environmentally valuable plants that are also useful for man, including herbs.

Oxycoccus palustris is a native species of utility peatland plants occurring quite commonly in the Łęczna-Włodawa Lakeland, as confirmed by field reconnaissance research performed in the years 2011-2013.

Other species of cranberry, i.e. Oxycoccus microcarpus and O. macrocarpus, are domesticated anthropophytes. They are slightly less common in nature, but more frequently cultivated (Stobnicka and Gniewosz, 2010). They were not observed at the selected natural study sites.

Due to its characteristic sweet-bitter taste and attractive colour, the fruit of all three species of cranberry has been used for culinary purposes for centuries (jams, confitures, juices, addition to sauces or beverages). It has also been an important component of phytotherapy, with effectiveness confirmed by traditional application and pharmacological studies (Hong and Wrolstad, 1986; Rodowski, 2001; Stobnicka and Gniewosz, 2010; Senderski, 2015).

The culinary and medicinal usefulness of cranberry is also manifested by the popularity of harvesting the herbal resource from nature, the common cultivation of popular cultivars, particularly the big fruit cranberries, e.g. Ben Lear, Bergman, Pilgrim, or Stevens (Mazur et al., 2009), as well as the popularity of sale of ready food products and herbal medicines (Stobnicka and Gniewosz, 2010).

Similarly as the content of bioactive substances and mass of the resource during vegetation in the case of herbs, the abundance of the population of many plant species can be determined by the variability of the environment. The effect of climatic (e.g. temperature, day light duration, precipitation) and soil-habitat factors, i.e. reaction, fertility, water relations, soil structure, content of organic substances, or content of different elements in the soil solution, and biocoenotic relations determine both the individual development and the abundance of individuals in the population (Stackevičiené and Labokas, 2000; Falińska, 2004; Kazimierczak et al., 2010; Lyuticova and Turov, 2011; Senderski, 2015; Usmanov et al., 2016; Serafin et al., 2017).

Observations conducted in the years 2011-2013 showed that in spite of the relatively common occurrence, the abundance of the population of small cranberry on peatlands in the central part of East Poland differs from site to site. In the case of the selected sites representative of the region, numerous populations of the species occurred in the area of 
lake-peatland complexes Karaśne, Dekowina, Moszne, and Długie (K, DK, M, and D group I), where their contribution in phytocoenoses of the analysed areas varied from $10 \%$ (D) to $30 \%(\mathrm{~K})$. In the remaining study areas, the contribution of O. palustris in phytocoenoses was considerably lower (from $2 \%$ - B to $4 \%$ - BZ - group II).

A total of 43 spermatophytes (description Fig. 2) from 19 botanical families were identified in the assemblages of both groups of sites, in different phytocoenotic configurations. Species such as Carex rostrata, Equisetum limosum, Betula pubescens, as well as Comarum palustre and Menyanthes trifoliata - herbs subject to simultaneous habitat research (Serafin et al., 2017; and unpublished data) - occurred constantly, although with different percent contributions at all of the study sites.

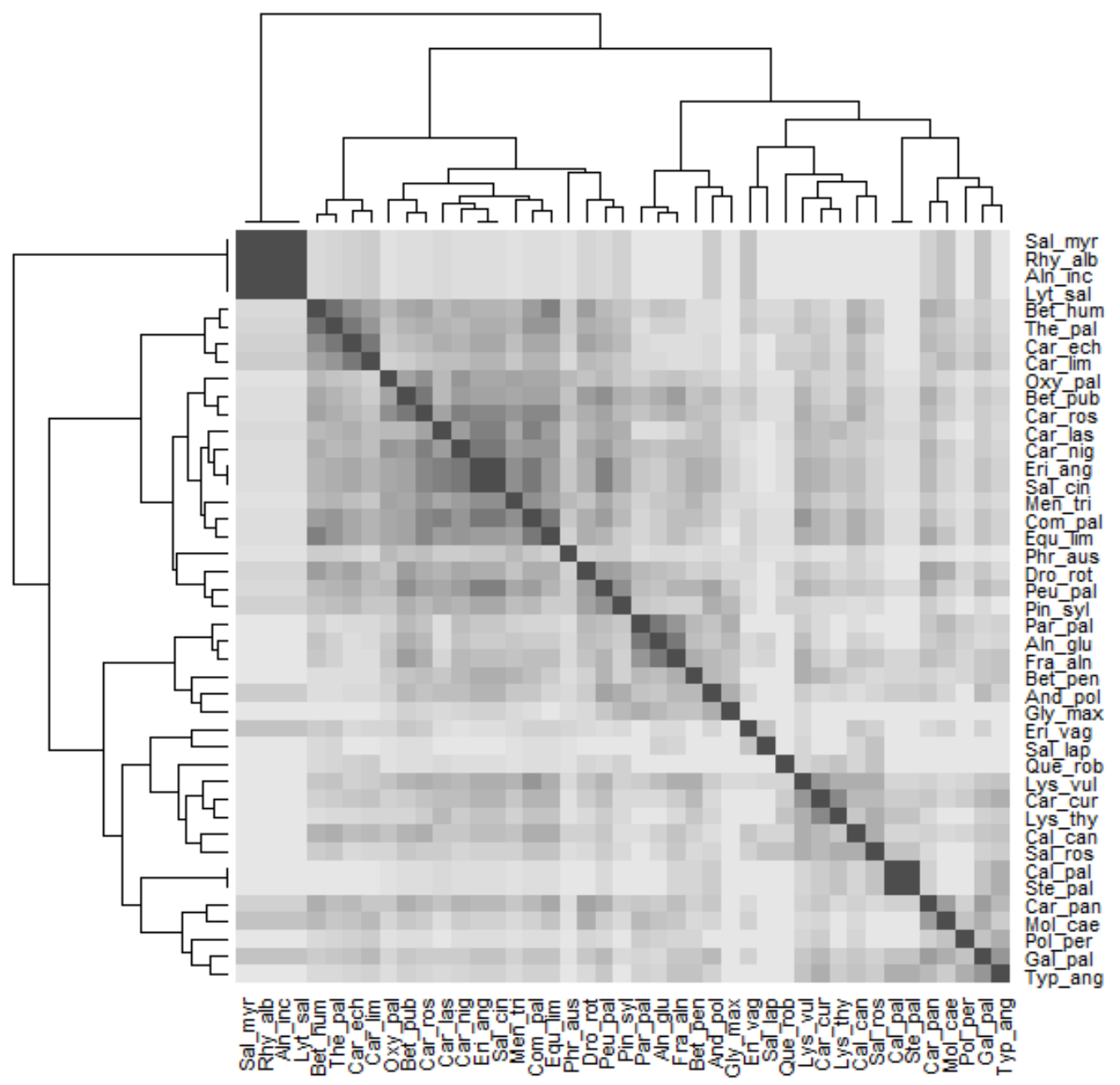

Figure 2. Dendrogram and heatmap of hierarchical cluster analysis of 43 species based on Jaccard's coefficient and Ward method. Species composition of phytozenoses: Alnus glutinosa, Alnus incana, Andromeda polifolia, Betula humilis, Betula pendula, Betula pubescens, Calamagrostis canescens, Calla palustris, Carex curta, Carex echinata, Carex lasiocarpa, Carex limosa, Carex nigra, Carex panacea, Carex rostrata, Comarum palustre, Drosera rotundifolia, Equisetum limosum, Eriophorum angustifolium, Eriophorum vaginatum, Frangula alnus, Galium palustre, Glyceria maxima, Lysimachia thyrsiflora, Lysimachia vulgaris, Lythrum salicaria, Menyanthes trifoliata, Molinia caerulea, Oxycoccus palustris, Quercus robur, Parnassia palustris, Peucedanum palustre, Phragmites australis, Pinus sylvestris, Polygonum persicaria, Rhynchospora alba, Salix cinerea, Salix lapponum, Salix myrtilloides, Salix rosmarinifolia, Stellaria palustris, Thelypteris palustris, Typha angustifolia 
The combination of the classic dendrogram and heatmap, for which colour intensity is directly proportionate to the degree of similarity, permitted a more thorough classification analysis of the species composition. Here, a division covering four assemblages of plant species occurs (Fig. 2). They were also analysed in phytosociological terms.

Assemblage I - includes species Alnus incana, Lythrum salicaria, Rhynchospora alba, and Salix myrtilloides, grouped together due to their single occurrence at individual sites (Fig. 3). Assemblage II - includes species showing a stronger tendency of joint occurrence at the same sites than the remaining species in other groups: Betula humilis, Comarum palustre, Equisetum limosum, Eriophorum angustifolium, Menyanthes trifoliata, Peucedanum palustre, (class: Scheuchzerio-Caricetea - fens and transitional bogs); Betula pubescens, Drosera rotundifolia, Oxycoccus palustris, Pinus sylvestris (class: Oxycocco-Sphagnetea - raised bogs), Phragmites australis, Salix cinerea, Thelypteris palustris (class: Alnetea glutinosae - marshy forests with black alder and thickets), and Carex echinata, Carex lasiocarpa, Carex limosa, Carex nigra, and Carex rostrata (Fig. 3) with variable phytosociological association. This assemblage includes the analysed species Oxycoccus palustris. Associations III and IV include species with variable phytosociological associations, with a weaker tendency of joint occurrence (according to Zarzycki and Korzeniak, 2002).

The Jaccard's coefficient of species similarity of the analysed phytocoenoses rarely and inconsiderably exceeded the value of 0.5 , which suggests variability of the flora between both groups of sites and within each of the groups (Serafin et al., 2017).

Somewhat more complete information is provided by the classification analysis with the Jaccard's coefficient as the similarity measure, performed for sites (Fig. 3).

In spite of the typological similarity, characteristic of the peatlands of the central part of East Poland, in the case of the classification of sites, a division into three groups is designated: I- D, M, B - sites with high similarity of species composition; II- DK, K sites showing mutual similarity of species composition and considerably lower towards group I; III- BZ - site with the lowest similarity of species composition towards the remaining groups (Fig. 3).

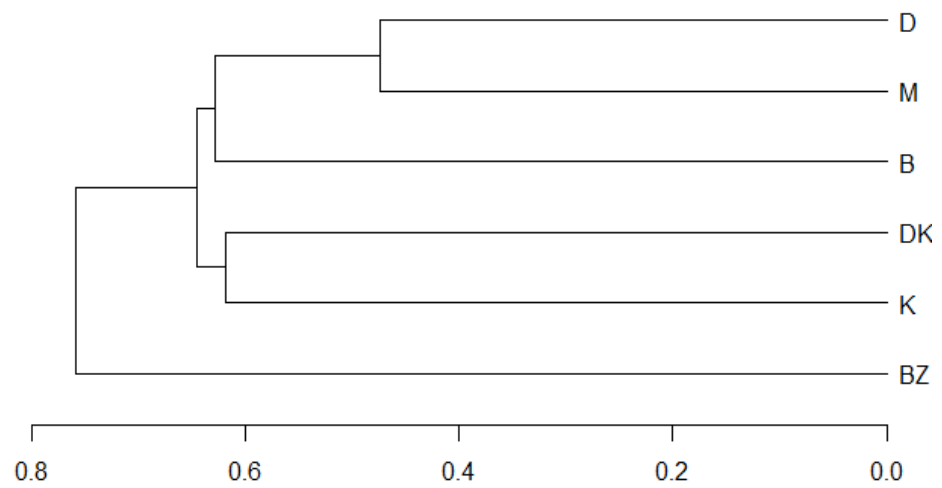

Figure 3. Dendrogram of hierarchical cluster analysis of 6 phytocoenoses based on Jaccard's coefficient and complete linkage method

Group 1 includes sites within active, typologically similar lake-peatland complexes (lakes: Długie (D), Moszne (M), and Bikcze - B), which determines their species similarity. Group 2 includes sites variable in terms of genesis - peatland complex not 
directly related to a water body - Dekowina (DK) and lake-peatland complex Karaśne $(\mathrm{K})$, where the final stages of ecological succession occur leading to complete overgrowing of the water body - perhaps the common basis for species similarity in the group. The site in group 3, namely the Blizionki range (BZ), is a small area remaining after a shallow water body, which although typologically corresponds with preferences of the analysed species, is characterised by the lowest species similarity towards the remaining groups. In combination with the low \% contribution of occurrence of $O$. palustris, this encourages searching the explanation of the fact in the abiotic properties of the habitat.

In phytosociological terms, the presented plant species compositions are dominated by species from classes: Scheuchzerio-Caricetea, Alnetea glutinosae, and OxycoccoSphagnetea closely associated with the ombrogenic habitats of raised and transitional bogs (Matuszkiewicz, 2001). This confirms the adequacy of selection of the study sites. Small cranberry is a species characteristic of shrub-peat assemblages from class: Oxycocco-Sphagnetea occurring on raised bogs, in acidic oligotrophic and dystrophic habitats fed primarily or exclusively by precipitation waters (Matuszkiewicz, 2001).

The botanical and the phytosociological analyses, however, do not constitute a significant factor affecting the greater abundance of phytocoenoses in small cranberry (classification of sites in relation to a higher \% share of $O$. palustris does not correspond to the classification of maximum species similarity). Therefore, the other factors favoring a better condition of the studied species should be found.

Therefore, values of the physical-chemical properties of the habitat, analysed in groundwaters in the years 2011-2013, provide a more complete image of habitat preferences of the analysed species, additionally determining the ranges of its ecological tolerance towards the analysed physical-chemical factors based on its variable population abundance (Table 1).

Table 1. Values of physical-chemical factors of piezometric waters at study sites on peatlands in the central part of East Poland (Polesie Podlaskie) with preliminary statistical analysis (Serafin et al., 2017). $\mathrm{N}_{\text {total }} \mathrm{N}-\mathrm{NH}_{4}, \mathrm{~N}-\mathrm{NO}_{3}, \mathrm{~N}-\mathrm{NO}_{2}, \mathrm{P}_{\text {total }}, \mathrm{P}-\mathrm{PO} \mathrm{O}_{4}, \mathrm{~S}-\mathrm{SO}_{4}, \mathrm{DOC}, \mathrm{Na}$, $\mathrm{K}, \mathrm{Ca}, \mathrm{Mg}\left[\mathrm{mg} \mathrm{dm}^{-3}\right], \mathrm{CON}\left[\mu \mathrm{Sm}^{-1}\right]$

\begin{tabular}{c|c|c|c|c|c|c}
\hline FACTOR & Min & Max & Median & Mean & SD & V\% \\
\hline $\mathbf{N}_{\text {Total }}$ & 0.05 & 182.8 & 7.14 & 22.56 & 35.48 & 157 \\
$\mathbf{N}^{-N_{4}}$ & 0.10 & 5.00 & 0.21 & 0.75 & 1.17 & 157 \\
$\mathbf{N}_{\mathbf{N O}}$ & 0.05 & 0.12 & 0.05 & 0.05 & 0.01 & 24 \\
$\mathbf{N}_{3}$ & 0.10 & 0.68 & 0.10 & 0.15 & 0.13 & 89 \\
$\mathbf{P}_{\text {Total }}$ & 0.04 & 1.78 & 0.34 & 0.42 & 0.40 & 96 \\
$\mathbf{P - P O}_{4}$ & 0.10 & 4.55 & 0.10 & 0.53 & 0.86 & 162 \\
$\mathbf{S - S O}_{4}$ & 0.10 & 40.19 & 0.27 & 2.15 & 6.70 & 311 \\
$\mathbf{D O C}$ & 16.90 & 84.10 & 42.54 & 45.15 & 18.46 & 41 \\
$\mathbf{C O N}$ & 32.60 & 381.30 & 105.10 & 129.04 & 85.06 & 66 \\
$\mathbf{p H}$ & 4.62 & 6.50 & 5.50 & 5.61 & 0.45 & 8 \\
$\mathbf{N a}$ & 3.30 & 249.60 & 6.70 & 18.53 & 43.92 & 237 \\
$\mathbf{K}$ & 0.85 & 9.55 & 3.16 & 3.76 & 2.29 & 61 \\
$\mathbf{C a}$ & 0.96 & 75.10 & 17.10 & 24.26 & 18.36 & 76 \\
$\mathbf{M g}$ & 0.14 & 6.03 & 1.88 & 2.05 & 1.34 & 65 \\
\hline
\end{tabular}


Due to considerable deviations of individual results, mean values of the majority of factors (e.g. Na, Ca, DOC, CON, $\mathrm{N}_{\text {total }}, \mathrm{P}_{\text {total }}, \mathrm{S}-\mathrm{SO}_{4}$, ) sometimes exceeded the range of typical observation distribution. The fact determined the somewhat misleading image of the intensity of a given property irrespective of the group of sites (Table 1), however not the exceeding values typical of the preferred habitat (following Zarzycki and Korzeniak, 2002).

The ranges of values of some of the factors (i.e. $\mathrm{N}_{\text {total }}, \mathrm{P}-\mathrm{PO}_{4}, \mathrm{DOC}$, and to a lower degree $\mathrm{K}$ and $\mathrm{Ca}$ ) depending on the group of sites variable in terms of population abundance of the analysed species were sometimes incoherent, additionally influencing the broader amplitude of environmental valency for the small cranberry. For the group of sites with a higher percent contribution of the analysed species $(M+K+D+D K)$, lower values in comparison to a group with its low contribution $(\mathrm{B}+\mathrm{BZ})$ were observed for $\mathrm{P}_{\text {total }}, \mathrm{P}_{-} \mathrm{PO}_{4}$, and DOC, and higher for $\mathrm{Ca}$ and $\mathrm{Mg}$ ions, respectively (Fig. 4).

Values of the remaining factors (e.g. Na, S-SO $\mathrm{SO}_{4}, \mathrm{total}, \mathrm{CON}$, etc.) were characterised by similar ranges in reference to two designated groups of sites, therefore they had no limiting effect (compare Fig. 4).
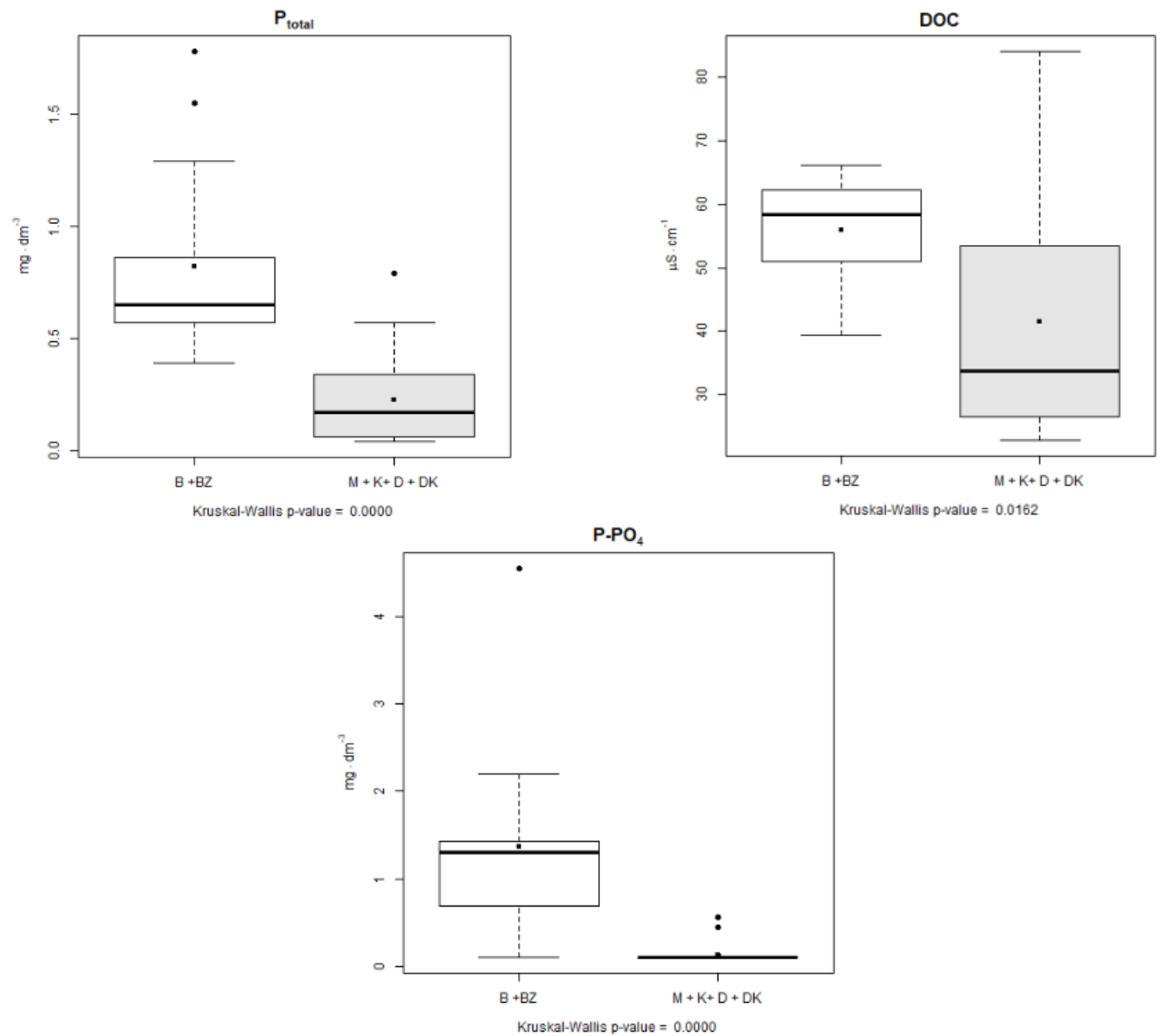

Figure 4. Distribution of values of the investigated physical-chemical factors of piezometric groundwater which may have a limiting effect on the studied population at the study sites in the period 2011-2013. The x axis label provides the p-value derived by the Kruskal-Wallis test. The horizontal line across the central region of the box represents the median. The mean value of the data is marked by a filled square. Any observation not included between the whiskers is considered as an outlier and represented by a filled circle 
A non-parametric Kruskal-Wallis test was performed to verify the variation in the distribution of values of the investigated parameters at particular sites. Statistically significant differences were only observed in the case of distribution of values of three factors: $\mathrm{P}_{\text {total }}, \mathrm{P}_{-} \mathrm{PO}_{4}$, and DOC (Fig. 4), which may have a limiting effect on the population size of $O$. palustris. The reduced values of the above parameters may be particularly considered a condition favouring higher occurrence of the studied species. Statistics of distribution of values of the factors (upper and lower quartile) therefore suggest ranges optimal for the functioning of the population of the studied species: $\mathrm{P}_{\text {total }}=0.17-0.36 ; \mathrm{P}_{-} \mathrm{PO}_{4}=0.1$, and $\mathrm{DOC}=33.81-55.90\left[\mathrm{mg} \cdot \mathrm{dm}^{-3}\right]$. In the case of factors $\mathrm{N}_{\text {total }}, \mathrm{N}-\mathrm{NO}_{2}, \mathrm{~N}-\mathrm{NO}_{3}, \mathrm{~N}-\mathrm{NH}_{4}, \mathrm{~S}-\mathrm{SO}_{4}, \mathrm{pH}, \mathrm{CON}$ as well as $\mathrm{Mg}, \mathrm{Ca}, \mathrm{Na}$ and $\mathrm{K}$, the distribution of each of the factors was found to be invariant in relation to the sites studied (Figs. 4 and 5).
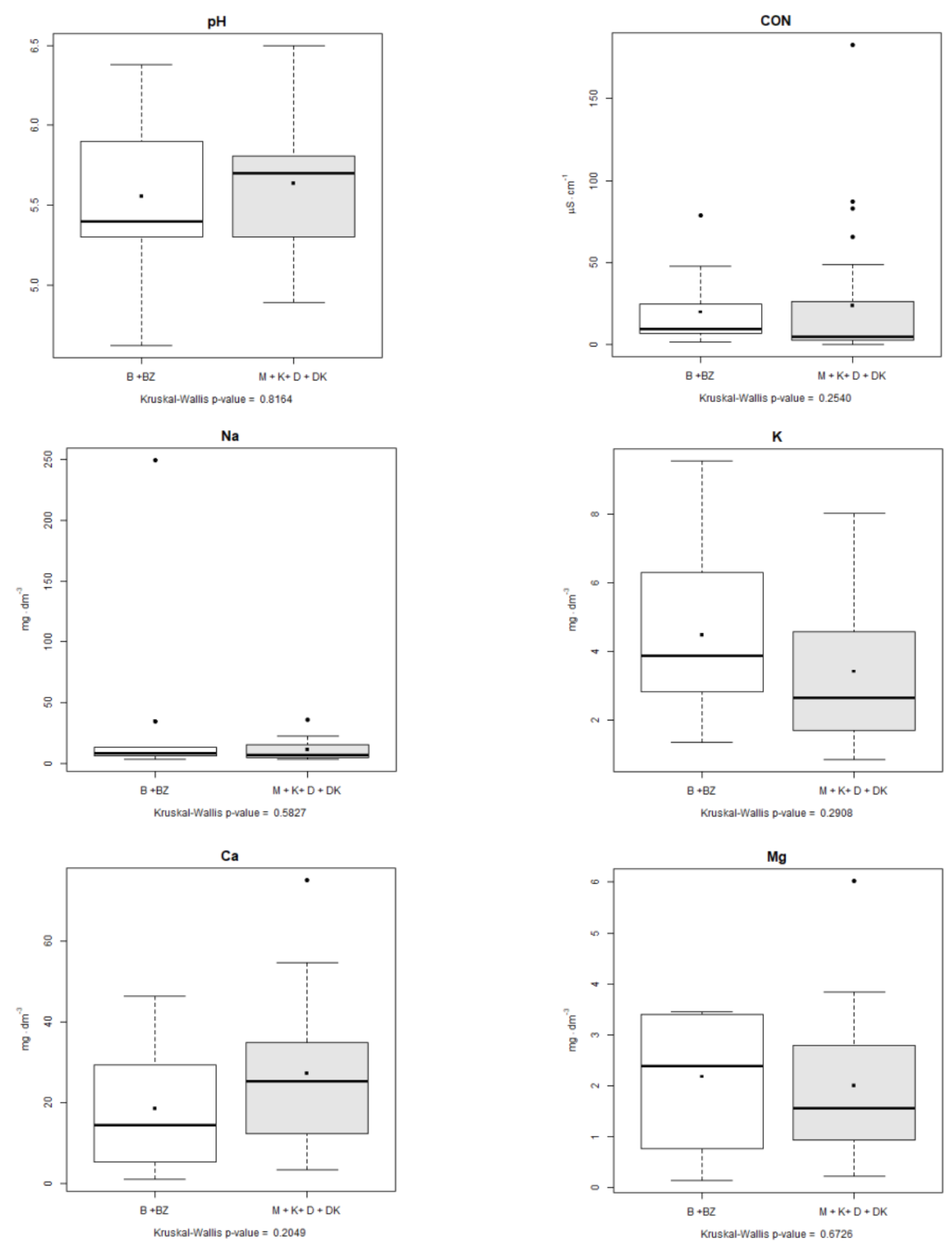


$$
-4024 \text { - }
$$
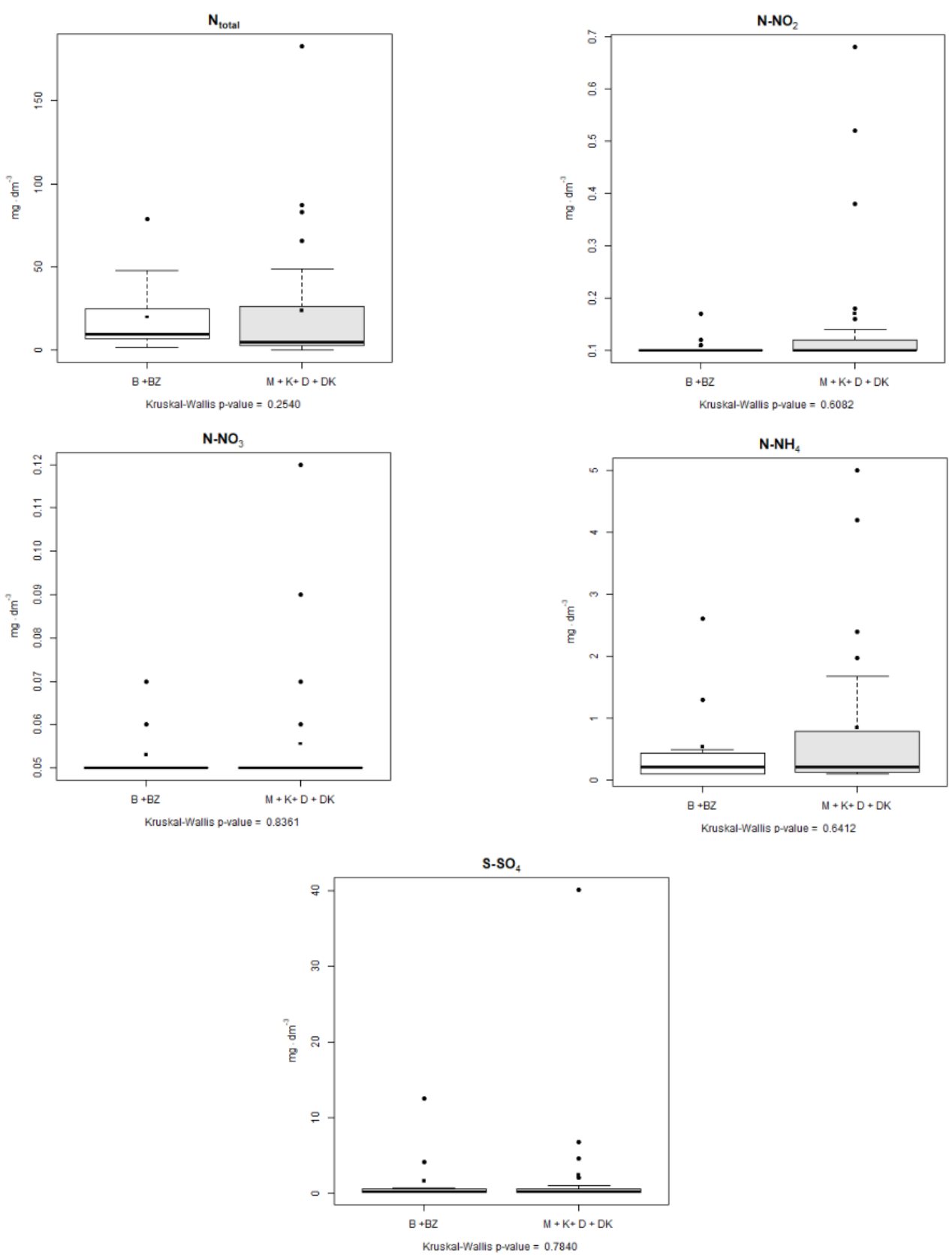

Figure 5. Distribution of values of the other investigated physical-chemical factors of piezometric groundwater at the study sites in the period 2011-2013

For comparison, simultaneous research conducted in the area for another species of herbal plant Menyanthes trifoliata showed that although both species prefer the same type of habitat, factors determining better condition of the population of the latter include: higher level of $\mathrm{N}_{\text {total }}, \mathrm{P}_{\text {total }}$, and low values of $\mathrm{pH}$ and $\mathrm{CON}$. Values of the remaining analysed factors, invariant in relation to different sites, had no limiting effect for the occurrence of the species (Serafin et al., 2017).

The next stage of the analysis employed direct ordination methods. The ordination analysis included 34 species (species characterised by the occurrence of single 
individuals at only one or two sites were excluded), 6 study sites, and 14 environmental variables.

The data set was first subject to detrended correspondence analysis (DCA) which showed a first-axis gradient length of 1.16 in standard deviation units. Therefore, we decided to apply redundancy analysis (RDA) using the rda function in the vegan package (Oksanen et al., 2016).

Prior to the analysis, redundant environmental variables (with linear correlation coefficient $|r|>0.6$ ) were omitted to avoid collinear rite (Blanchet et al., 2008). For this reason and also taking into account the Kruskal-Wallis test results, we carried out RDA with 4 selected environmental explanatory variables: $P_{\text {total }}, \mathrm{N}_{\text {total }}, \mathrm{DOC}$ and CON. Before performing further analyses, environmental data were log-transformed (using $\log (y+1))$ and standardised to meet the assumption of normality. Furthermore, we decided to apply Hellinger transformation to the species data (Legendre and Gallagher, 2001).

RDA results were used to produce ordination diagrams with scaling $=1$ and scaling $=2$ (Fig. $6 a$ and $b$, respectively). All environmental variables accounted for $78.58 \%$ of the total variation. The first two RDA axes explained $53.86 \%$ of the total variation in the species data $($ RDA1 $=35.17 \%$, RDA2 $=18.69 \%)$. The distances between the sites were approximate Euclidean distances (Fig. 6a). Therefore, sites ordinated closer together (like B, K, BZ and also D, M) can be expected to have a similar species composition and similar values of environmental variables. In this context, site DK is not similar to any of the other sites. Moreover, DK is characterised by high level of $\mathrm{N}_{\text {total }}$ (Fig. 6b). Sites B, K, BZ are characterised by high $\mathrm{CON}$ and $\mathrm{P}_{\text {total }}$ levels. Variable $\mathrm{N}_{\text {total }}$ appeared to be associated to the positive part of axis 1 . CON occupies the opposite part of the axis. The second axis is positively correlated with DOC and $\mathrm{P}_{\text {total }}$.

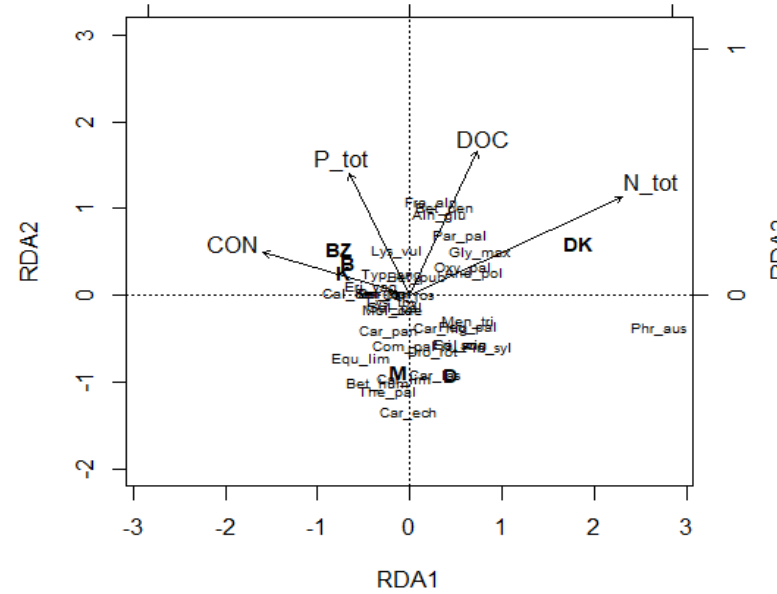

(a) scaling $=1$

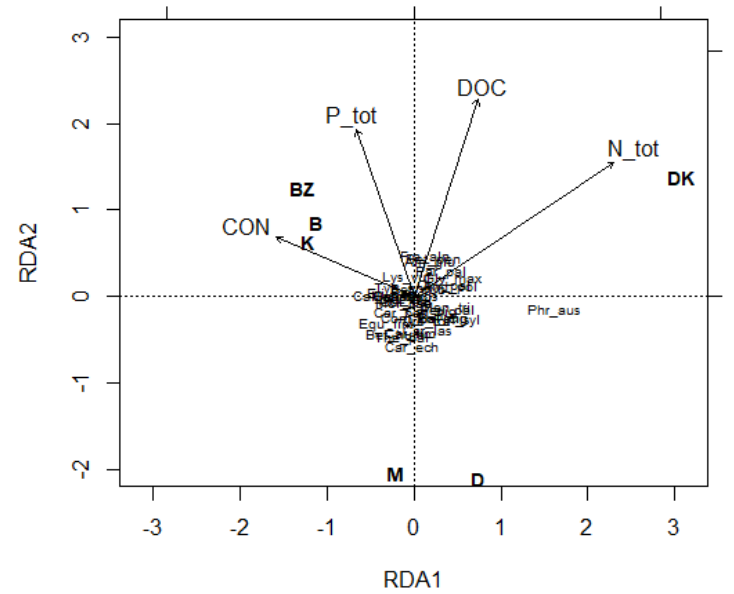

(b) scaling $=2$

Figure 6. Triplot of the RDA with fitted site scores, species and environmental variables as arrows

The triplot (Fig. 6b) indicates a positive correlation between $\mathrm{N}_{\text {total }}$ and DOC, and a similar magnitude correlation between $\mathrm{CON}$ and $\mathrm{P}_{\text {total }}$, and between $\mathrm{P}_{\text {total }}$ and DOC. We found a near-zero correlation between DOC and CON, as well as between as $\mathrm{P}_{\text {total }}$ and 
$\mathrm{N}_{\text {total. }}$. In terms of species-environment associations, we observed that the studied species Oxycoccus palustris was strongly positively associated with $\mathrm{N}_{\text {total }}$.

The habitat research and statistical analyses concerning selected physical-chemical parameters of peatland waters confirm the relatively broad spectrum of ecological tolerance for small cranberry. This is manifested by the common occurrence of the species on peatlands in East Poland. Nonetheless, the condition of its population can be determined by different habitat and biocoenotic factors determining the growth and development of the population, and therefore its abundance at different sites. More abundant occurrence of $O$. palustris in places with reduced human impact allows for the presumption that due to the evolutionally developed optimum habitat preferences, the composition and content of biologically active substances in its organs are more natural. Obtaining the herbal resource from such natural sites in accordance with the rules of Good Manufacturing Practice permits the production of natural herbal medicines pursuant to the guidelines of WHO (Borkowski, 1994; Drozd, 2012). In many cases, it is impossible to determine which biologically active compound has medicinal importance. Therefore, the properties of the herbal resource such as natural composition and the natural composition of medicinal factors, confirmed by the traditional application and effective treatment, seem to be of importance.

In the case of harvesting the herbal resource from nature, area restrictions exist, and sometimes also legal restrictions related to forms of nature protection areas. Ecological cultivations retaining optimum natural values of physical-chemical properties of habitats seem to be an excellent alternative, particularly in reference to conventional cultivations (Serafin et al., 2017) dominated by other species of cranberry more seldom occurring in nature (Stobnicka and Gniewosz, 2010).

The consequence of the habitat research will be the laboratory analysis of the content of biologically active substances obtained from the therapeutic raw material of small cranberry at all study sites for comparative purposes, and the perspective of the experiment of organic cultivation of this species in conditions optimised by these study results.

\section{Conclusions}

1. In the area of peatlands of Central-East Poland, Oxycoccus palustris is a species with a broad range of ecological tolerance in reference to the majority of the analysed physical-chemical habitat properties.

2. Values of the analysed habitat parameters, although variable depending on the study site, did not exceed values typical of preferences of the species, which translated into its common occurrence.

3. Lower values of concentration of important habitat parameters in ranges: $\mathrm{P}_{\text {total }}=0.17-0.36 ; \mathrm{P}_{-} \mathrm{PO}_{4}=0.1$, and $\mathrm{DOC}=33.81-55.90\left[\mathrm{mg} \cdot \mathrm{dm}^{-3}\right]$ can be considered as a condition favourable for proper functioning of individuals of the analysed species.

\section{REFERENCES}

[1] Adamczak, A., Buchwald, W., Kozłowski, J., Mielcarek, S. (2009): The effect of thermal and freeze drying on the content of organic acids and flavonoids in fruit of European cranberry (Oxycoccus palustris Pers.). - Herba Polonica 55(3): 94-102. 
[2] Arnal, B., Bureau, L., le Jeune, R. (2008): La canneberge d'Amĕrique, proprieties et indications. - Phytotherapie 6: 129-132.

[3] Blanchet, F. G., Legendre, P., Borcard, D. (2008): Forward selection of explanatory variables. - Ecology 89(9): 2623-2632.

[4] Borkowski, B. (ed.). (1994): Rośliny lecznicze w fitoterapii. - Instytut Roślin I Przetworów Zielarskich, Poznań.

[5] Brinkmann, H, Wibmeyer, K, Gehrmann, B. (2007): Fitoterapia - racjonalne porady I zalecenia. - Medpharm, Wrocław.

[6] Buettner, C., Mukamal, K. J., Gardiner, P., Davis, R. B., Phillips, R. S., Mittleman, M. A. (2009): Herbal supplement use and blood lead levels of United States adults. - Journal of General Internal Medicine 24(11): 1175-1182.

[7] Česonienè, L, Daubaras, R., Areškevičiūtè, J., Viškelis, P. (2006): Evaluation of morphological peculiarities, amount of total phenolics and anthocyanins in berries of European Cranberry (Oxycoccus palustris). - Baltic Forestry 12(1): 59-63.

[8] Drozd, J. (2012): Wczoraj i dziś - ziołolecznictwa. - Przegląd Medyczny Uniwersytetu Rzeszowskiego i Narodowego Instytutu Leków w Warszawie, Rzeszów T2: 245-251.

[9] Falińska, K. (2004): Ekologia roślin. - Wydawnictwo Naukowe WN, Warszawa.

[10] Herbach, J. (2001): Zróżnicowanie i problemy ochrony roślinności torfowisk Pojezierza Kaszubskiego. - Acta Botanica Cassubica 1: 59-69.

[11] Hong, V., Wrolstad, R. E. (1986): Cranberry juice composition. - JAOAC Int. 69: 99107.

[12] Jaquemart, A-L. (1997): Vaccinum oxycoccus L. (Oxycoccus palustris Pers.) and Vaccinum microcarpum (Turcz. Ex Rupr.) Schmalh. (Oxycoccus microcarpus Turcz. Ex Rupr.). - Journal of Ecology 85(3): 381-396.

[13] Jasnowski, M. (1972): Rozmiary i kierunki przekształceń szaty roślinnej torfowisk. Phytocoenosis 1(3): 193-209.

[14] Jepson, R. G., Craig, J. C. (2008): Cranberries for preventing urinary tract infections (Review). - Cochrane Database of Systematic Reviews 2008(1): Art. No.: CD001321.

[15] Kazimierczak, R., Hallmann, E., Kazimierczyk, M., Rembiałkowska, E. (2010): Antioxidants content in chosen spice plants from organic and conventional cultivation. Journal of Research and Applications in Agricultural Engineering 55(3): 164-170.

[16] Legendre, P., Gallagher, E. D. (2001): Ecologically meaningful transformations for ordination of species data. - Oecologia 129(2): 271-280.

[17] Lyutikova, M. N., Turov, Y. P. (2011): Chemical constituens from wild Oxycoccus palustris fruit from north Tyumen Oblast. - Chemistry of Natural Compounds 46(6): 848-852.

[18] Matuszkiewicz, W. (2001): Przewodnik do oznaczania zbiorowisk roślinnych Polski. Wyd. PWN, Warszawa.

[19] Mazur, B., Borowska, E. J., Polak, M. (2009): Zawartość witaminy C i pojemność przeciwutleniająca owoców i przecierów z żurawiny błotnej i wielkoowocowej. ŻYWNOŚĆ. Nauka. Technologia. Jakość 2(63): 130-137.

[20] Michalska-Hejduk, D., Kopeć, D. (2010): Szata roślinna torfowiska Żabieniec - stan obecny i dynamika. - In: Twardy, J., Żurek, S., Forysiak, J. (eds). Torfowisko Żabieniec: warunki naturalne, rozwój i zapis zmian paleoekologicznych w jego osadach. Bogucki Wydawnictwo Naukowe, Poznań, pp. 75-87.

[21] Nowiński, M. (1983): Dzieje upraw i roślin. - Państwowe Wydawnictwo Rolnicze I Leśne, Warszawa.

[22] Oksanen, J. F., Blanchet, G., Kindt, R., Legendre, P., Minchin, P. R., O'Hara, R. B., Simpson, G. L., Solymos, P., Henry, M., Stevens, H., Wagner, H. (2016): Vegan: Community Ecology Package. $\mathrm{R}$ package version 2.4-1. - http://CRAN.Rproject.org/package=vegan. 
[23] Olaczek, R., Kucharski, L., Pisarek, W. (1990): Zanikanie obszarów podmokłych I jego skutki środowiskowe na przykładzie województwa piotrkowskiego (zlewni Pilicy I Warty). - Studia Ośrodka Dokumentacji Fizjograficznej 18: 141-199.

[24] Oliveira, S. G. D., De Moura, F. R. R., Demarco, F. F., Da Silva Nascente, P., Del Pino, F. A. B., Lund, R. G. (2012): An ethnomedicinal survey on phytotherapy with professionals and patients from basic care units in the Brazilian Unified Health System. Journal of Ethnopharmacology 140(2): 428-437.

[25] Piernik, A. (2008): Metody numeryczne w ekologii. - Wyd. UMK, Toruń.

[26] R Core Team (2015): R: A language and environment for statistical computing. - R. Foundation for Statistical Computing, Vienna, Austria. https://www.R-project.org/.

[27] Rodowski, D. (2001): Żurawina - nowe spojrzenie na właściwości lecznicze. - Postępy w fitoterapii (2-3): 28-31.

[28] Ruzik-Kuklińska, U. (2010): Rośliny lecznicze. - Wyd. Bellona, Warszawa.

[29] Senderski, M. E. (2015): Prawie wszystko o ziołach i ziołolecznictwie. - Wydawnictwo własne, Podkowa Leśna.

[30] Serafin, A., Pogorzelec, M., Bronowicka-Mielniczuk, U. (2017): The specificity of natural habitats of Menyanthes trifoliata L. in peat bogs of the central part of Eastern Poland. - Applied Ecology and Environmental Research 15(3): 849-859.

[31] Skotnicka, M. (2013): Rola ziół w żywieniu osób starszych - badanie pilotażowe. Problemy Higieny i Epidemiologii 94(3): 635-638.

[32] Stackevičiené, E., Labokas, J. (2000): Fruiting peculiarities of wild cranberry (Oxycoccus palustris L.) in Čepkeliai bog. - Sodininskysté ir Daržininkysté 19(3): 255-264.

[33] Stobnicka, A., Gniewosz, M. (2010): Możliwości wykorzystania właściwości żurawiny (Oxycoccus) we współczesnej medycynie. - Postępy Fitoterapii 3: 170-175.

[34] Usmanov, I. Y., Yumagulova, E. R., Ovechkina, E. S., Ivanov, V. B., Shcherbakov, A. B., Aleksandrova, V. V., Ivanov, N. A. (2016): Fractal analysis of morpho-physiological parameters of Oxycoccus palustris Pers. in oligotrophic swamps of Western Siberia. - An International Journal of Plant Research 29(1): 1-3.

[35] Zarzycki, K., Korzeniak, U. (ed.). (2002): Ecological Indicator Values of Vascular Plants of Poland. - Inst. Botaniki PAN, Kraków.

[36] Zuur, A. F., Ieno, E. N., Smith, G. M. (2007): Analysing Ecological Data. - Springer, New York. 